\title{
ABO BLOOD GROUPS, HUMAN HISTORY AND LANGUAGE IN HEREFORDSHIRE WITH SPECIAL REFERENCE TO THE LOW B FREQUENCY IN EUROPE
}

\author{
I. MORGAN WATKIN \\ County Health Department, Aberystwyth
}

Received 6.x.64

\section{INTRODUCTION}

HEREFORDSHIRE is repeatedly referred to in Domesday as lying in Wales and the county is regularly described as such in the Pipe Rolls until 1249-50. Of the two dozen or so charters granted to the county town, a number are addressed to the citizens of Hereford in Wales. That fluency in Welsh was until 1855 one of the qualifications for the post of clerk to the Hereford city magistrates indicated the county's bilingual nature.

The object of the present investigation is to ascertain whether there is any significant genetic difference between the part of Herefordshire conquered by the Anglo-Saxons and the area called "Welsh Herefordshire". As some moorland parishes have lost 50 per cent. of their inhabitants during the last 50 years, the need to carry out the survey is the more pressing.

\section{THE HUMAN HISTORY OF HEREFORDSHIRE \\ Pre-Norman Conquest}

Offa's general line of demarcation between England and Wales in the eighth century extending in Herefordshire from near Lyonshall to Bridge Sollars, about five miles upstream from Hereford, is intermittent in the well-wooded lowlands, being only found in the Saxon clearings. From this Fox (1955) infers that the intervening forest with its dense thickets of thorn and bramble filling the space under the tree canopy was an impassable barrier. Downstream to Redbrook (Glos.) the river was probably the boundary but the ferry crossing from Beachley to Aust and the tidal navigational rights up the Wye were retained by the Welsh-facts which suggest that the Dyke was in the nature of an agreed frontier.

It is a fact, according to Fox (1959), that the Anglo-Saxons were seldom interested agriculturally in the lighter soils. They settled beside rivers and streams and cultivated the land nearby preferring the deep meadow to the hill pasture. Present-day farming practice, according to Thomas (1964), differs on opposite sides of Offa's Dyke especially if one compares the adjoining counties of Radnor and Hereford. Radnorshire has typically an upland pasture economy for the county has the highest proportion of land above $700 \mathrm{ft}$. in the whole of Wales. In 
Herefordshire, on the other hand, there is an arable system of farming based on some of the best land in the country associated with red sandstone. While rainfall in Radnorshire can reach 50 in. a year, there is in Herefordshire a more equable climate associated with an annual rainfall of $30 \mathrm{in}$. It is frequently assumed that the Anglo-Saxons failed to conquer Wales because of the resistance put up by the Welsh whose ally was the mountainous nature of the country. Darlington (I964), however, thinks that the Anglo-Saxon colonisation was conditioned by the potentialities of the land for their imported type of farming practice and not by military operations. Examples of this principle are, he states, widespread as in Abyssinia, Bengal and Azerbaijan.

In A.D. 9 I 5 the Vikings advanced into Archenfield and Ewyas and not many miles from Hereford captured Cyfeiliog, a Welsh bishop.

\section{Norman times}

The men of Erging or Archenfield are referred to in Domesday Book as Welsh and the area which they inhabited-south-west Herefordshire between the Wye, the Monnow and the Worm-is described as lying in Wales. In the reign of Henry III, however, reference is made to a Welsh colony living on the mountain strip near Kilpeck (Archenfield) called the "Mynde" - an example of the separation of the lands of the lordship into an "Englishry" and a "Welshry". The former, as W. Rees (1924) points out, usually lay in the more lowland parts and consisted of the castle, the manor and the borough. It harboured the foreign elements in the population. The latter, on the other hand, embraced the more upland regions where the Welsh continued to live in their scattered homesteads.

At the time of Domesday all parts of Archenfield were alike in never having been " hidated". Round (1908) claims that if a district is assessed in "hides", it indicates an ancient English possession. If the land is reckoned in "carucates" it is looked upon as having been acquired in a more recent epoch. Thus on the Wye as on the Dore, Domesday allows us to trace the boundary lines of ancient conquest where the English had here and there fought their way across the stream. Thus in the valley of the Dore the eastern bank is assessed in hides as is Bacton, on the right bank, which lies in the diocese of Hereford. But Ewyas Harold, in a Welsh diocese just below it on the same bank, is assessed in "carucates".

Although there had been Norman infiltration into Herefordshire in the time of Edward the Confessor, it was not until the Conqueror that castles were erected with chartered boroughs beneath their walls. These led to the arrival of French traders, priests, as well as soldiers. Municipal rights were also offered as bribes to attract settlers from Normandy. As a consequence Herefordshire became, according to Bannister (I 9 I 2), the most Normanised county in England. 


\section{Post-Norman times}

The general disorder in the Marches-an area where the King's writ did not run, covering much of what is now Shropshire, Herefordshire and Gloucestershire-led the Tudors to convert the Marches into shire ground and clearly define the boundary between England and Wales. The line, as Rees (1947) points out, could not, unlike the diocese, be justified on geographical, historical, racial or linguistic grounds.

After the Acts of Union, Welshmen came down from the hills as seasonal workers and later took over numbers of English farms which could not support a gentleman farmer and hired labour-a system alien to Wales where father, sons and daughters worked on the farm. Thus, in the twentieth century, the pattern of human settlement in the borderland is beginning to assume a form similar to that which existed before the Norman lord took possession of the lowlands and relegated the Welsh to an upland existence.

\section{PHYSICAL ANTHROPOLOGY}

The earliest known inhabitants of Herefordshirc-the Silures-are described by Tacitus as having a dark complexion. This he ascribed to their Iberian origin. The etymology of the name Silures, like the name Ewyas, has so far baffled Celtic scholars. Reference in a scventhcentury B.c. Phoenician periplus to a "Mons Silurus" in Spain is perhaps significant.

The average stature of adult males in Herefordshire-under $5 \mathrm{ft}$. $6 \frac{1}{2}$ in.--was according to the Report of the British Association's Anthropometric Committee (I883) among the lowest in the British Isles. Apart from London and its environs, persons of such short stature were confined to a belt of territory extending south from Shropshire to embrace the southern shore of the Bristol Channel as far as Somerset and the coastal counties of South Wales. Beddoe's index of nigrescence was as high in Herefordshire as it was in North Wales-a figure twice that found in England generally. As in Wales, there were undoubtedly local variations for Edward Lhuyd ( $\mathrm{y} 700$ ) stated that the complexion of the Eardisland parishioners was, for the most part, fair. Unfortunately no detailed physical anthropological study of Herefordshire has been carried out.

\section{LANGUAGE}

When the Domesday Survey was undertaken, a jury from the township or "tref", or from the manor where such was established, was summoned and to its members previously prepared interrogatories were addressed. The use of Welsh translators or "latimers" was common in western Herefordshire and not unknown, according to W. Rees (1962), on some churchlands even to the east of Hereford city.

Bannister (1912) mentions that every holder of land in Kentchurch 
in I 300 was Welsh. The Visitation Returns of the diocese of Hereford for 1397 record that many of the parishioners of Garway and Wormbridge knew no English.

The Act of Parliament of 1563 charged the bishop of Hereford as well as the four Welsh bishops with the translation of the Bible and the Book of Common Prayer into Welsh. The Welsh Bible of 1809 and the Welsh Prayer Book of $184 \mathrm{I}$ were also issued under his authority. Similarly in ${ }_{1} 53^{8}$ Thomas Voisey, Bishop of Exeter, enjoined his clergy to read all or part of the gospel or epistle of the day in the Cornish tongue where English was not spoken.

"Many here speak Welsh", is the description of the town of Hereford in a State Paper of 1642 . Enderbie in 1661 states that the Welsh tongue is commonly spoken "Englandwards as in Herefordshire". Places mentioned include Ewyas Lacy, Ewyas Harold, Clifford, Winforton, Eardisley, Huntington, Whitney and Stapleton. Richards (1925) states that a meeting house was erected in Longtown as early as 1692 and the Independents were ready to raise $f$ ro per year to keep a minister if he were able to preach in English and in Welsh. Edward Lhuyd ( 1707 ) describes Eirinwg - an old Welsh name for Herefordshire-as the habitat of the Gwenhwysaeg Welsh dialect. In I 794 the Gymanfa Ddeheuol (Southern Assembly) of the Baptists was held at Olchon in the lee of the Black Mountains but the proceedings, although printed in Welsh, reveal that the sermons and prayers were delivered alternately in Welsh and in English. The holding of bilingual services by nonconformists is a more reliable pointer to the decline of the Welsh language in a particular area than a similar arrangement in the established church where the use of English, for the benefit of the squire and those who would emulate him was and is still not uncommon even in thoroughly Welsh-speaking areas.

On the hills near Yazor, a mere eight miles from the town of Hereford, Welsh had survived well into the eighteenth century according to Southall (1893). The proximity of the early Saxon settlements at Withington and Ashperton scarcely twelve miles to the east of the town is, Southall states, a remarkable example of separate languages surviving for 1000 years within twenty miles of each other.

Instructions to churchwardens, according to Clive (1867), were printed in parallel columns in English and Welsh in some of the churches near Kentchurch in the nineteenth century. In the Welshspeaking parts the parish registers, as is always the case, are written in Latin or English but the trades or occupations of the individuals noted are often given in Welsh, thus saer (carpenter), gof (blacksmith). In I883, according to Owen (I 906 ), the last Welsh-speaking native of Clodock - a hamlet on the eastern slopes of the Black Mountains-died, but at the turn of the century Welsh was still spoken by adults in Ffwyddog, in the heart of the mountain range, and at the head of the Dore Valley. 


\section{Place names}

In Herefordshire, Welsh place names are most numerous in the heart of Archenfield, while along the Wye and in the north they are few in number. Half the field and farm names of Archenfield are Welsh and in other parts of western Herefordshire the proportion is greater. In Kington itself no Welsh names are found whereas those of Huntington are half Welsh and in Brilley, three miles south, considerably more than half.

In the conquered part of the country, the village names are overwhelmingly English which convinces Bannister (1916) that the settlements of the invading Mercians were quite different from the later acquisitions of the Normans. The latter appropriated existing settlements whereas the English, several centuries earlier, had established new settlements of a kind and in places entirely different from anything that they had found in these parts. Where Saxon place names thickly cover the map it merely implies, in Chadwick's view (1963), that the Saxons were living in concentrated communities, the Geltic population in the open country.

\section{THE COUNTY AND THE DIOCESE}

When western Mercia was divided into shires at the beginning of the tenth century, Archenfield and Ewyas were not included in Herefordshire as they were still Welsh and independent. Under the Acts of Union of $153^{6-42}$ several lordships and towns were detached from Wales and added to Herefordshire and during the nineteenth century Welsh Bicknor, near Ross-on-Wye, was annexed to Herefordshire while Bwlch Tre-Wyn, near Llanthony, and the detached portion of Herefordshire known as Ffwyddog, were transferred to Monmouthshire.

At the time of Domesday, Archenfield and Ewyas lay in Welsh dioceses but, despite boundary changes, eleven Ewyas parishes remained in a Welsh diocese until 1852. The Welsh Church Disestablishment Act of 1914 required the Ecclesiastical Commissioners to attach to an English diocese any ecclesiastical parish which was situate in a Welsh diocese but not in Wales or Monmouthshire. Thus in 1920 when the Act came into force, Welsh Herefordshire lost one of its last remaining links with Wales.

\section{TECHNIQUE}

The blood samples were obtained from civilian dorors attending the clinics of the National Blood Transfusion Service and bloodgrouping was carried out on both cells and serum. The record card of every person who had given blood was taken into account, for the active donor panel alone, i.e. those who are called upon to donate blood regularly, does not truly reflect the blood-group distribution in the population.

Surnames. The list of surnames accepted as Welsh was published in 
1956. Beddoe (1885) noted that in Herefordshire one-third of the farmers, artisans and small shopkeepers had Welsh surnames but among the upper classes the proportion was barely one-sixth. In Archenfield the proportion of Welsh surnames was greater. Almost all the names on tombstones from Ross to Pontrilas and from Hereford to Skenfrith were Welsh, according to Bradley (I905). Beddoe (I 885) stated that in East Herefordshire Welsh surnames were as uncommon in the hilly and inaccessible as in the lower-lying and more accessible parishes. From this he concluded that the East was entirely anglicised.

\section{ABO BLOOD-GROUPS}

\section{(i) The $O$ and $A$ gene frequencies}

Fisher and Taylor (1940) noted that as one travels northward in England the $O$ gene frequency rises. In south-western England, Fraser Roberts (I948) found an $O$ gene frequency of 66.7 per cent. but in the northern counties it had risen to 70.3 per cent. Across the Scottish border in West Inverness and East Ross peaks of $76 \cdot 9$ and 76.5 per cent. were recorded by Kirkpatrick (1952).

With the exception of a few circumscribed areas of Scandinavian settlement, the $O$ gene frequency in Wales is higher than in similar latitudes in England. Herefordshire is also higher in $O$ than North Gloucestershire and very much higher than East Anglia. This general picture conceals some interesting variations. When Herefordshire is divided along the line of Offa's Dyke, the $O$ gene frequency on the western or Welsh side is higher and the $A$ gene frequency lower than on the eastern or English side (table 2). The difference, however, is not statistically significant $\left(\chi^{2}=2.99\right.$ and $\left.\mathrm{P}>0.05\right)$. A further subdivision of the donors into those with English and those with Welsh surnames shows that the $O$ and $A$ gene frequencies of persons with Welsh surnames differ significantly on the two sides of the Dyke $\left(\chi^{2}=I \mathrm{I} \cdot 78\right.$ and $\mathrm{P}$ lies between $0.00 \mathrm{I}$ and $\left.0.000 \mathrm{I}\right)$. The same, however, is not true of persons with English surnames.

One would expect persons with Welsh surnames on the western side of the Dyke to have the lowest and those with English surnames on the eastern side the highest $A$ gene frequency. Although the former is shown to be the case, by far the highest $A$ gene frequency on the eastern side is found not in persons having English but in those with Welsh surnames. Fraser Roberts (1948) came across a similar but less marked trend in "two areas adjacent to Wales", namely the Cheltenham and the Bristol areas. After mentioning that "donors with Welsh family names are actually slightly higher in $A$ than the population amongst which they live", he concludes that the majority of Welsh names in the Cheltenham and Bristol areas are derived from South Wales. Furthermore, in view of the sex-ratio, much of the immigration must, he states, be very recent. Yet a study of persons with Welsh surnames in the industrial valleys of South Wales (Watkin, I965) reveals that only in West Monmouthshire and East Glamorgan 
and in the lower Swansea valley is an $A$ gene frequency similar to that in the Cheltenham and Bristol areas found. In Mid-Glamorgan the percentage $A$ and $O$ gene frequencies are 22.5 and $70 \cdot 6$, and further west in the upper part of the Swansea valley, 20.3 and 7 I. I respectively.

TABLE I

Numbers observed in Herefordshire towns and villages

\begin{tabular}{|c|c|c|c|c|c|c|c|c|}
\hline \multirow{3}{*}{ Name of town or village } & \multicolumn{8}{|c|}{ Numbers } \\
\hline & \multicolumn{4}{|c|}{ English surnames } & \multicolumn{4}{|c|}{ Welsh surnames } \\
\hline & $o$ & $A$ & $B$ & $A B$ & $o$ & $A$ & $B$ & $A B$ \\
\hline East & & & & & & & & \\
\hline $\begin{array}{l}\text { Leintwardine, Richard's Castle, Wig- } \\
\text { more, Lingen, Kinsham and Titley }\end{array}$ & 62 & 29 & 10 & I & $5^{\circ}$ & $5^{1}$ & 7 & 4 \\
\hline Leominster $\quad$. $\quad$. $\quad$. $\quad$. & 102 & 94 & 11 & 4 & 40 & $5^{1}$ & 3 & 4 \\
\hline Bromyard $\dot{\text { Canon Pyon and Mansell Lacy }} \cdot$ & $\begin{array}{r}106 \\
50\end{array}$ & $\begin{array}{r}91 \\
42\end{array}$ & $\begin{array}{r}16 \\
4\end{array}$ & 12 & $\begin{array}{l}33 \\
20\end{array}$ & $\begin{array}{l}30 \\
19\end{array}$ & $\begin{array}{l}5 \\
6\end{array}$ & ${ }^{2}$ \\
\hline Hereford. & $43^{2}$ & $\begin{array}{l}42 \\
382\end{array}$ & $\begin{array}{r}4 \\
54\end{array}$ & $\dddot{24}$ & 140 & 160 & 35 & 12 \\
\hline Ledbury, Cradley and Colwall & 128 & I3 I & 13 & 8 & 33 & 31 & 7 & 4 \\
\hline Ross & 103 & 97 & 14 & 7 & $3^{I}$ & 35 & 7 & I \\
\hline Total . & 983 & 866 & 122 & 56 & 347 & 377 & 70 & 27 \\
\hline West & & & & & & & & \\
\hline $\begin{array}{l}\text { Kington, Lyonshall, Eardisley, Whitney } \\
\text { and Cusop }\end{array}$ & 127 & 114 & 18 & 5 & I 70 & I 18 & 25 & I 6 \\
\hline $\begin{array}{l}\text { Bredwardine, Dorstone, Peterchurch, } \\
\text { Vowchurch, Kingstone and Madley }\end{array}$ & $5^{2}$ & 47 & 8 & I & 62 & 45 & 8 & I \\
\hline $\begin{array}{l}\text { Abbey Dore, Ewyas Harold, Worm- } \\
\text { bridge, Pontrilas, Longtown, Kent- } \\
\text { church and Garway }\end{array}$ & 57 & $9^{1}$ & 14 & 4 & 82 & 64 & 19 & 4 \\
\hline $\begin{array}{l}\text { Holme Lacy, Little Dewchurch, Llan- } \\
\text { garren and Llangrove }\end{array}$ & 43 & 36 & 3 & 3 & 61 & $5^{2}$ & 9 & 4 \\
\hline $\begin{array}{l}\text { Welsh Newton, Whitchurch and Good- } \\
\text { rich }\end{array}$ & 113 & 72 & I 5 & 7 & $5^{2}$ & 45 & 4 & 6 \\
\hline Total & $39^{2}$ & 360 & $5^{8}$ & 20 & 427 & 324 & 65 & $3^{1}$ \\
\hline
\end{tabular}

It would thus seem that those who moved from South Wales to Gloucestershire came in the main from the eastern part of the Coalfield. There is, however, no evidence of migration from industrial South Wales to rural Herefordshire during the inter-war years of industrial depression, and other factors must account for the increased number of $A$ genes found in persons with Welsh surnames in the eastern part of the county.

In a non-industrial county, good agricultural land acts as a magnet to the upland farmer. If persons with Welsh surnames in East Herefordshire are the offspring of immigrants from Wales, they probably came from the adjacent Radnorshire, Breconshire or Monmouthshire hills. But nowhere in these counties does one find a 


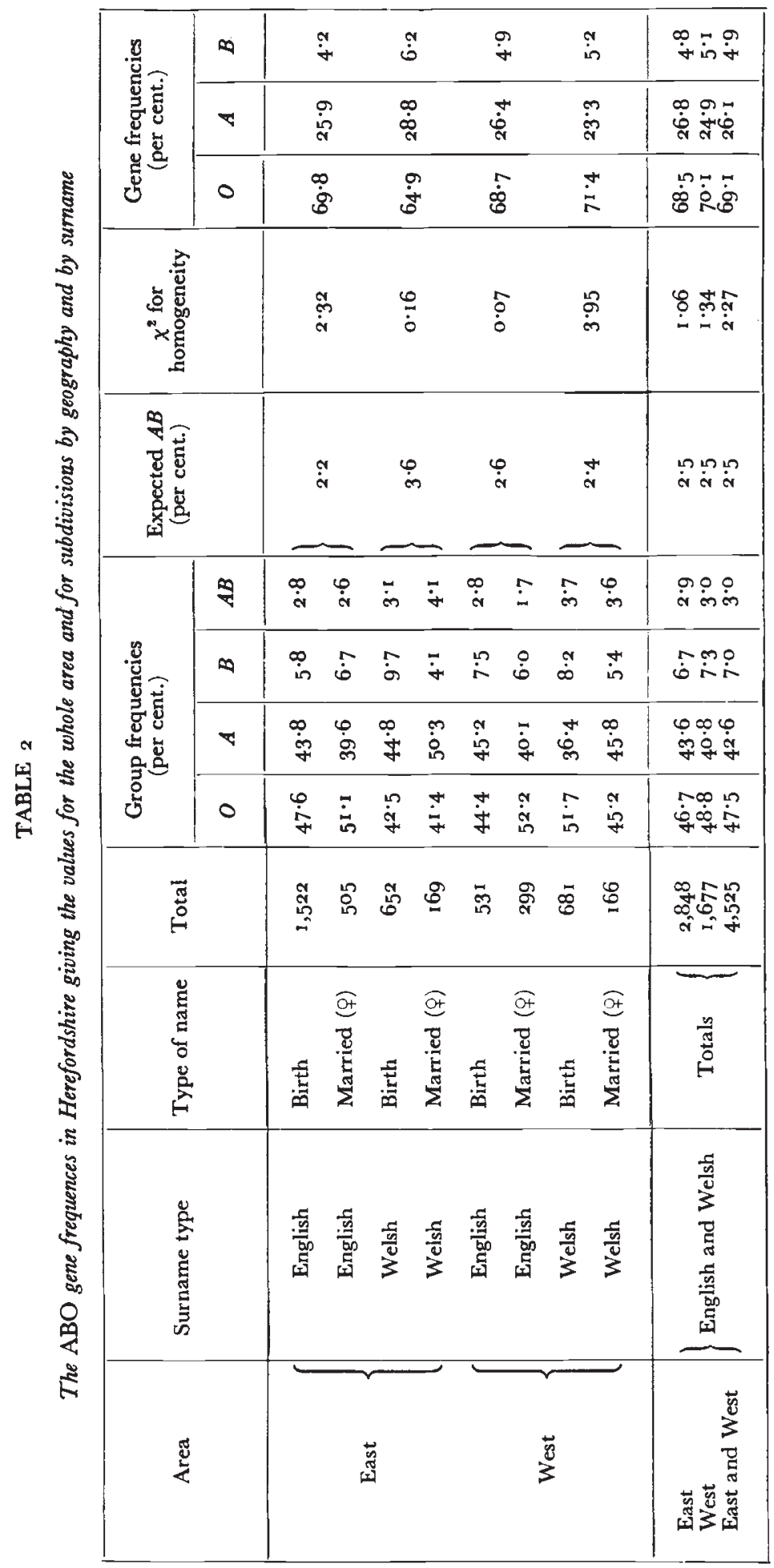


stock of similar serological composition. The people of the East Radnorshire hills have the following percentage gene frequencies: $O=62.8 ; A=24.9 ; B=10.5$, while the comparable figures for the Black Mountains are $71.5 ; 22.5 ; 6 \cdot 0$. As persons with English surnames in East Herefordshire are also relatively low in $A$, they alone

\section{HEREFORDSHIRE: O GENE FREQUENCY} (PERSONS WITH WELSH SURNAMES)

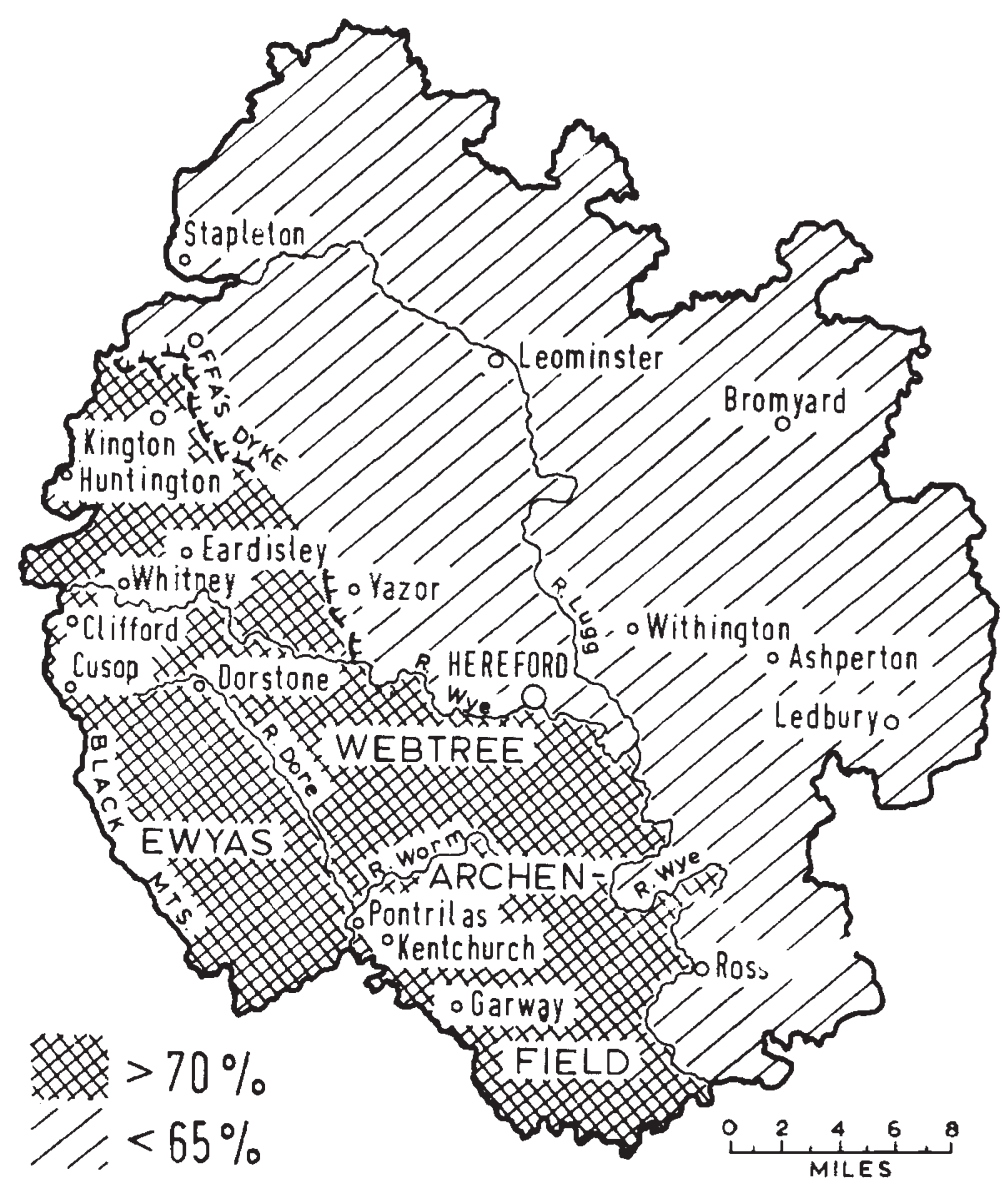

could not have accounted for the raised $A$ gene frequency of those with Welsh surnames. The apparently Welsh element in East Herefordshire is, therefore, a mixture to which East Radnorshire probably contributed many, the Black Mountains a few and some adjacent English counties an unknown quota of $A$ genes. Pin-pointing the contribution of the English counties must await the publication of more data but meanwhile the possibility of a high $A$ Norman ethnic contribution cannot be ignored. 
In West Herefordshire, on the other hand, those with Welsh surnames are almost identical serologically with the hill people of adjacent Breconshire and Monmouthshire. Insufficiency of numbers makes it impracticable to subdivide western Herefordshire into the Englishries and the Welshries.

\section{(ii) The B gene frequency}

The $B$ gene frequency in Herefordshire is appreciably lower than Dobson and Ikin's (1946) average of 6.0 per cent. for the United Kingdom. On the whole, $B$ is even higher in Wales, the average gene frequency in the eastern counties being 6.2 and in the western parts 7.6 per cent. Fraser Roberts (1953), when referring to the great local fluctuations in the $B$ gene frequency in the North of England, stated that future work might show if they bore a relation to history or geography, or if they had arisen mainly by chance. In view of the strong ties linking Herefordshire with Wales, and as low $B$ gene frequencies are a rarity in the Principality, it seemed worthwhile trying to search for clues that would clarify this unusual situation.

$A B O$ blood-group anthropological investigations usually consist of a comparison between one country and another or between parts of the same country. No investigation appears to have been undertaken, however, of the low $B$ gene frequency areas in relation to highland and lowland. If it is assumed that people with a $B$ gene frequency below the average for the United Kingdom show traces of their relationship to a stock in which $B$ was exceptionally low, light may be thrown on the relative dates of settlement of this stock in Europe if it is borne in mind that the mountains harbour earlier-arrived human strains than the plains.

The method adopted was to consult the tables of Mourant $e t$ al. (1958), supplemented by the results of Khérumian, of Gex and Bigel, of Ranque et al. (1960), and of Johnson et al. (1963). Areas or towns where the $B$ gene frequency of the population is 5.5 per cent. or under were noted. Thcy are referred to as "low $B$ areas". Pre-war results were discarded as $B$ was frequently under-estimated by the slide grouping technique. Where several sets of results have been published for a particular locality, the largest sample is selected.

In Morocco, Portugal, Spain, southern France and Switzerland, low $B$ communities are found on the highlands. On the other hand, on the mainland of Italy, as in Britain, they are confined to the lowlands - to the region described by Vidal de la Blache as "la plaine drainée par le Pô" together with a small adjacent area along the Adriatic seaboard. Contrary to the general European pattern, a rise in $B$ occurs as one moves from east to west in the north of peninsular Italy-exactly as in Wales.

It seems clear that a low $B$ people, wherever its original home may have lain, reached the mainland of Italy at a later period than Spain, southern France or Switzerland. The existence of low $B$ communities 
on almost every island already surveyed, from the central Mediterranean to Britain, suggests a seafaring folk. Was there, therefore, more than one low $B$ stock? If so, the low $B$ people who contributed to the make-up of the present-day Herefordshire population are likely to have belonged to the maritime branch. They probably gained entry along the Bristol Channel and the River Wye-as did the Vikings at a later date.

\section{SUMMARY}

1. Herefordshire was officially regarded as part of Wales for several centuries after the Norman Conquest. The Welsh language survived until the beginning of the twentieth century.

2. The blood-group results of 4525 donors show that there is a significant difference between those with Welsh surnames on the two sides of Offa's Dyke. Those living to the west closely resemble their neighbours on the Welsh side of the Black Mountains but the remainder are a mixture probably drawn from several adjacent Welsh counties, some English ones, with possibly a sprinkling of Norman blood. Persons with English surnames are similar on the two sides of the Dyke but their $O$ gene frequencies are higher than in similar latitudes in England.

3. As in Gloucestershire, the highest $A$ gene frequency is found not in persons with English but in those with Welsh surnames. The low $B$ gene frequency in Herefordshire - a feature most marked in those with English surnames-was probably introduced by a seafaring folk navigating the tidal waters of the Wye.

Acknowledgments.-I wish to thank Dr W. Weiner, Birmingham, and Dr R. J. Drummond, Cardiff, the medical directors of the National Blood Transfusion Service in the Midland Region and in Wales respectively, for offering me every facility to analyse the relevant blood-group record cards. Professor C. D. Darlington offered a number of very valuable suggestions, as did Sir Frederick Rees and Professor William Rees. Professor Khérumian, Paris, gave me several useful hints and Professor E. G. Bowen placed the library and mapping facilities of the Department of Geography and Anthropology, University College of Wales, Aberystwyth, at my disposal. Mr R. J. Thomas of the National Library of Wales, Aberystwyth, and Mr J. F. W. Sherwood, of the Hereford City Library, Museum and Art Gallery, drew my attention to some interesting references. I am grateful to all of these and to my wife who drew the map.

\section{REFERENCES}

BANNISTER, A. T. 1902. The History of Ezvias Harold. Hereford.

BANNister, A. T. 1912. Herefordshire and its Place in English History. Hereford.

bannister, A. т. 1916. The Place Names of Herefordshire. Cambridge.

BANNISTER, A. T. I929. Visitation returns of the diocese of Hereford in 1397. Eng. Hist. Rev., 44, 279-289.

BEDDOE, J. $\mathrm{J} 885$. The Races of Britain. Bristol.

BRADLEY, A. G. 1905. In the March and Borderland of Wales. London.

BRADNey, J. 1926. The Decay of the Welsh Language in the Eastern Part of Monmouthshire. Memorandum written at request of Departmental Committee, Board of Education. Abergavenny. 
CALENDAR OF STATE PAPERS DOMestic. i $641-43.492,399$. London.

CANDELA, P. B. 1942. The introduction of the $B$ gene into Europe. Hum. Biol., $14,4,413-443$.

CHADWICK, NORA K. I963. The British or Celtic part in the population of England. Angles and Britons. O'Donnell Lectures. Cardiff.

Charles, B. G. 1963. The Welsh, their language and place-names in Archenfield and Oswestry. Angles and Britons. O'Donnell Lectures. Cardiff.

Clive, A. 1867. Pres. Address Cambrian Arch. Soc. 2 ist Annual Meeting, Hereford. Arch. Camb., 13, Third Series, 396-398.

Darlington, C. D. 1964 . Personal communication.

DOBSON, AILEEN M., AND IKIN, ElizABETH w. 1946. The $A B O$ blood-groups in the United Kingdom: frequencies based on a very large sample. 7. Path. Bact., $58,2,221-227$.

ENDERBIE, P. I661. Cambria Triumphans. London.

FISHER, R. A., AND TAYLOR, G. L. 1940. Scandinavian influence in Scottish ethnology. Nature, 145, 590.

FleUre, H. J., AND Davies, E. 1958. Physical character among Welshmen. $7 . R$. anthrop. Inst., 88, I, 45-95.

Fox, c. 1955. Offa's Dyke. London.

Fox, c. 1959. The Personality of Britain. Cardiff. $4^{\text {th }}$ ed. amended.

GeX, madeleine, and bigel, P. 1960. Fréquence des gènes $A, B$ et $O$ dans le BasRhin. Transfusion, France, 3, 4, 353-362.

IKIN, ELIZABETH W., MOURANT, A. E., KOPEĆ, ADA C., MOOR-JANKoWsKI, J. K., AND HUSER, H. J. 1957. The blood-groups of the Western Walsers. Vox. Sang., 2 (new series), 159-I 74 .

JohNSON, R. H., IKIN, ELIZABETH W., AND MOURANT, A. E. 1963. Blood-groups of the Ait Haddidu Berbers of Morocco. Human Biol., 35, 4, 514-523.

KhÉRUMIAN, R. I96o. Répartition départementale des groupes sanguins $A B O$ en France métropolitaine. Transfusion, France, 3, 2, 163-180.

KIRKPatrick, H. J. R. 1952. Pers. comm. quoted by A. E. Mourant in The Distribution of the Human Blood-Groups. 1954. Oxford.

Kopeć, ADA C. 1956. Blood-groups in Great Britain. Advanc. Sci., Lond., 200-203. LhUYd, E. c. I 700. Parochialia, Part III, issued by Camb. Arch. Ass. 1909-19I I, 44. LHUYD, E. 1707. Archrologia Britannica. Oxford.

MOURANT, A. E., KOPEĆ, ADA C., AND DOMANIEWSKA-SOBCZAK, KAZIMIERA. 1958. The $A B O$ Blood-Groups. Oxford.

owen, H. 19o6. The English Conquest of West Herefordshire, Note E (Part 2) of George Owen's Pembrokeshire, Pt. 3, 264-276. London.

RANQUE, J., NICOLI, R. M., AND BATTAGLINI, P. F. I96o. Note préliminaire sur les groupes sanguins (système $A B O$, facteur $D$ ) des populations provençales. Transfusion, France, 3, 2, 181-185.

Rees, J. F. 1947. Tudor Policy in Wales. Studies in Welsh History. Cardiff. REEs, w. 1924. South Wales and the March. Oxford.

REEs, w. 1932. South Wales and the Border in the I 4 th Century. 4 maps. Southampton. REES, W. 1962. The Evolution of the Welsh Border. O'Donnell Lectures, Univ. of Oxford, 1959-61. Pers. Comm.

REES, W. H. 1947. The vicissitudes of the Welsh language in the Marches with special reference to its territorial distribution in modern times. Ph.D. thesis, Univ. of Wales.

RICHARDS, T. 1925. The religious census of 1676 ; an enquiry into its historical value, mainly in reference to Wales. Trans. Cym. Soc., 1-1 18.

ROBERTS, J. A. F. 1948. The frequencies of the $A B O$ blood-groups in South-Western England. Ann. Eugen., Lond., 14, 2, 109-1 16.

ROBERTS, J. A. F. 1953. An analysis of the $A B O$ blood-group records of the North of England. Heredity, 7, 3, 361-388.

Round, J. H. 1908. The Domesday Survey. V.C.H. Herefordshire, Vol. I. London. 
southall, J. E. 1893. Wales and her Language. Newport and London. 2nd ed. тномаs, Р. т. 1964. Personal communication.

WATKIN, I. M. 1956. $A B O$ blood-groups and racial characteristics in rural Wales. Heredity, $10,2,16 \mathrm{I}-193$.

WATKIN, r. M. 1964. English and Welsh racial elements in western Shropshire and in the adjacent Welsh borderland: $A B O$ blood-group evidence. F. $R$. anthrop. Inst., 94, $1,52-65$.

watkin, r. m. 1965. The Welsh element in the South Wales Coalfield: an anthropological study based on $A B O$ blood-groups. F. R. anthrop. Inst., in press. 